\title{
PENGARUH MOTIVASI, KESEHATAN KERJA, DAN KESELAMATAN KERJA (K3) TERHADAP KINERJA KARYAWAN PT. X DI BUMI SERPONG DAMAI
}

\author{
Riptono $^{1}$, Muhammad As'ad ${ }^{2}$, Mochamad Reza Hafriansyah ${ }^{3}$ \\ Institut Ilmu Sosial dan Manajemen Stiami \\ Email: riptono@stiami.ac.id,muhammad.asad@stiami.ac.id
}

\section{ARTIKEL INFO}

Keywords: $\quad$ Motivation, Occupational Health, Safety, Employee Performance

\section{ABSTRACT}

This research aim to analyze the effect of Motivation, Occupational Health, and Safety (OHS) on Employee Performance.The amount of population are 70 employee in $P T X$ and 59 people were sampled by Morgan \& Krecjie table.Based on research resultsindicates that: Partially show that motivation has a positive and significant influence amounted to 78,9\% of employee Performance. In the second Partial results showed that Occupational Health has no positive and significant impact on employee performance by $19 \%$. In the third Partial results showed that Safety has an inverse and significant impact by $60,1 \%$ on Employee Performance. The independent variables Motivation, Occupational Health, and Safety are jointly tested by $F$ test proved positive and significant influence on Employee Performance and the magnitude of the effect seen from coefficient of Determination (R2) is $35,4 \%$.

\section{PENDAHULUAN}

Karyawan akan memiliki kinerja yang baik, apabila mereka dapat mematuhi peraturan yang diberlakukan perusahaan, seperti sistem manajemen K3 salah satunya. Tingkat absensi karyawan PT X di Bumi Serpong Damai dalam 4 tahun terakhir mengalami peningkatan dari tahun ke tahun. Terutama pada periode tahun 2017 dimana presentase ketidak hadiran mencapai 30\%. Tingkat ketidakhadiran karyawan yang paling rendah terjadi pada tahun 2014 yang mencapai persentase $20 \%$, dengan standar perusahaan tidak boleh kurang dari $80 \%$.

Hal ini mengharuskan manajerial untuk memperbaiki tingkat absensi karyawannya agar dapat meningkatkan kinerja karyawan dan mencapai tujuan perusahaan. Salah satunya dengan meningkatkan Motivasi, kesehatan kerja dan keselamatan kerja yang diperoleh para karyawan.

Menurut Robbins (1996) kinerja merupakan fungsi interaksi antara kemampuan atau ability (A), motivasi atau motivation $(\mathrm{M})$ dan kesempatan atau Opportunity $(\mathrm{O})$, yaitu Kinerja $=\mathrm{f}(\mathrm{A} \times \mathrm{M} \times \mathrm{O})$. Hal ini berarti kemampuan dan kemauan atau dorongan dan semangat kerja seseorang bisa jadi dihadapkan pada rintangan yang menghambat optimalisasi perwujudan kinerja seseorang.

Kinerja karyawan berhubungan dengan motivasi kerja di perusahaan. Hubungan kerja dalam hal ini adalah kinerja karyawan yang terjadi disebabkan oleh karyawan itu. Peranan motivasi kerja dan kesehatan dan keselamatan kerja berkaitan dengan kinerja karyawan dalam suatu perusahaan terlebih lagi perusahaan tersebut telah menjalankan system manajemen kesehatan dan keselamataan kerja.

Oleh karena itu, dikaitkan dengan kesehatan dan keselamatan kerja dengan motivasi kerja diperusahaan. Peneliti mencoba melihat lebih jauh apakah variabel motivasi, variabel kesehatan kerja dan keselamatan kerja dapat memberikan kontribusi atau pengaruh terhadap kinerja karyawan.

\section{Perumusan Masalah}

(1) Seberapa besar pengaruh motivasi terhadap kinerja karyawan PT X di Bumi Serpong Damai ? (2) Seberapa besar pengaruh kesehatan kerja terhadap kinerja karyawan PT X di Bumi Serpong Damai ? (3) Seberapa besar pengaruh keselamatan kerja terhadap kinerja karyawan PT X di Bumi Serpong Damai ? (4) Seberapa besar pengaruh Motivasi, Kesehatan Kerja, dan Keselamatan Kerja bersama-sama terhadap kinerja karyawan PT X di Bumi Serpong Damai? 


\section{Manfaat Penelitian}

(1) Manfaat Teoritis ; Sebagai penunjang dalam penerapan Ilmu Manajemen SDM khususnya mengenai meningkatkan kinerja karyawan dan dapat dijadikan bahan pendukung untuk penelitian selanjutnya. (2) Manfaat Praktis ;Sebagai penunjang untuk meningkatkan kinerja karyawan dengan memperbaiki motivasi kerja karyawan dan aspek Kesehatan dan Keselamatan Kerja (a) Bagi PT X diharapkan dapat dijadikan sebagai salah satu bahan masukan dan sumbangan pemikiran yang berarti dalam meningkatkan motivasi kerja karyawan dalam meningkatkan kinerja karyawan.

\section{KAJIAN LITERATUR}

\section{Kinerja Karyawan}

Menurut The Sriber Bantam English Dictionary terbitan Amerika Serikat dan Canada, tahun 1979 (dalam Prawirosentono, 1999:12) "to perform" mempunyai beberapa "entries" berikut: (1) to do or Carry out; executive, (2) to discharge or fulfill, as a vow, (3) to party, as a character in a play, (4) to render by the voice or musical instrument, (5) to execute or complete on undertaking, (6) to act a part in a play, (7) to perform music, (8) to do what is expected of person or machine.

Stolovitch and Keeps (1992:34) mengemukakan bahwa: "Kinerja merupakan seperangkat hasil yang dicapai dan merujuk pada tindakan pencapaian serta pelaksanaan sesuatu pekerjaan yang diminta". Casio (1992:137) mengemukakan: "Kinerja merujuk kepada pencapaian tujuan karyawan atas tugas yang diberikan". Donnelly, et al (1994:210) mengemukakan: "Kinerja merujuk kepada tingkat keberhasilan dalam melaksanakan tugas serta kemampuan untuk mencapai tujuan yang telah ditetapkan. Kinerja dinyatakan baik dan sukses jika tujuan yang diinginkan dapat tercapai dengan baik. Bernardin dan Russell (1993:379) menyebutkan bahwa: "Performance is defined as the record of outcomes produced on a specified job function or activity during a specified time period.

Dikutip suryadi dan rosyidi 2013, Kinerja menurut Handoko (2000) adalah kegiatan dan hasil yang dapat dicapai atau dilanjutkan seseorang atau sekelompok orang di dalam pelaksanaan tugas, pekerjaan dengan baik, artinya mencapai sasaran atau standar kerja yang telah ditetapkan sebelum dan atau bahkan dapat melebihi standar yang ditentukan oleh perusahaan pada periode tertentu. Sementara Mahsun (2006) mendefinisikan kinerja adalah gambaran mengenai tingkat pencapaian pelaksanaan suatu kegiatan atau program atau kebijakan dalam mewujudkan sasaran, tujuan, misi dan visi organisasi yang tertuang dalam rencana strategi suatu organisasi (Achmad Suryadi, Hamim Rosyidi, 2013).

Faktor-faktor yang mempengaruhi kinerja seorang pegawai menurut Simanjuntak (2005) "digolongkan ke dalam 3 kelompok yaitu kompetensi individu orang yang bersangkutan, dukungan organisasi dan dukungan manajemen." Kompetensi individu adalah kemampuan dan keterampilan melakukan kerja, Dukungan organisasi dalam peningkatan kinerja karyawan dilakukan melalui pengorganisasian pegawai, penyediaan sarana dan prasarana kerja, pemilihan teknologi, kenyamanan lingkungan kerja, serta kondisi dan syarat kerja, dan Dukungan Manajemen yaitu Kemampuan manajerial perusahaan atau pimpinan perusahaan juga sangat menentukan kinerja setiap individu yang akhirnya akan menentukan kinerja perusahaan itu sendiri (Sony Haryanto, 2012)

Sementara itu dikutip suryadi dan rosyidi 2013, Anwar Prabu Mangkunegara (2000) menyatakan kinerja (prestasi kerja) adalah hasil kerja secara kualitas dan kuantitas yang dicapai oleh seseorang pegawai dalam melaksanakan tugasnya sesuai dengan tanggung jawab yang diberikan kepadanya.

Manfaat Penilaian Kinerja (1) Bagi Pegawai/ karyawan yang dinilai (a) Manfaat penilaian kinerja bagi pegawai antara lain untuk meningkatkan motivasi, kepuasan kerja, dan adanya kejelasan standar hasil yang diharapkan. (2) Bagi manajerManfaat penilaian kinerja bagi manajer diantaranya untuk (a) mengetahui kecenderungan kinerja pegawai (b) mengembangkan sistem pengawasan yang baik, sebagai media untuk meningkatkan interpersonal relationship. (3) Bagi PerusahaanManfaat penilaian kinerja bagi perusahaan diantaranya untuk (a) meningkatkan pandangan secara luas menyangkut tugas yang dilakukan oleh masing-masing pegawai, (b) perbaikan seluruh simpul unitunit yang ada dalam perusahaan. 


\section{Motivasi Kerja}

Motivasi berasal dari bahasa latin movere yang berarti dorongan atau daya penggerak. Motivasi (motivation) dari pengertian itu maka bisa diambil kesimpulan bahwa sesungguhnya motivasi adalah dorongan yang menggerakkan seseorang untuk melakukan suatu aktivitas atau tindakan tertentu. Dalam kehidupan, motivasi memiliki peranan yang sangat penting karena motivasi adalah hal yang menyebabkan, menyalurkan, dan mendukung perilaku manusia, supaya mau bekerja giat dan antusias mencapai hasil yang optimal. Pada dasarnya perusahaan bukan saja mengharapkan karyawan yang "mampu, cakap, dan terampil", tetapi yang terpenting keterampilan untuk mencapai produktivitas yang tinggi ( Hasibuan, 2007 : 92). Tanpa adanya motivasi dalam diri seseorang maka dapat dipastikan bahwa orang itu tidak akan bergerak sedikitpun dari tempatnya berada (Eny Muslikah, 2011).

Siagian sebagai-mana dikutip oleh Soleh Purnomo (2004 : 36), menyatakan bahwa motivasi adalah daya pendorong yang mengakibatkan seseorang anggota organisasi mau dan rela untuk menggerakkan kemampuan dalam bentuk keahlian atau keterampilan, tenaga dan waktunya untuk menyelenggarakan berbagai kegiatan yang menjadi tanggung jawabnya dan menunaikan kewajibannya, dalam rangka pencapaian tujuan dan berbagai sasaran organisasi yang telah ditentukan sebelumnya.

Siagian (2004 :255), menyatakan bahwa keinginan seseorang dari pekerjaan yang ditekuni pada umumnya adalah sesuatu yang mempunyai arti penting bagi dirinya sendiri dan bagi instansi. Heidjachman dan Husnan (2003 : 197), menyatakan motivasi merupakan proses untuk mencoba mempengaruhi seseorang agar melakukan sesuatu yang di inginkan.

Motivasi diharapkan dapat mempengaruhi kinerja karyawan. Apabila motivasi tinggi serta didukung oleh kemampuan yang tinggi maka kinerja karyawan juga akan meningkat, dan sebaliknya. Hanya yang menjadi permasalahan adalah jika motivasi tinggi tetapi tanpa didukung oleh kemampuan dan semangat kerja yang tinggi, maka karyawan tersebut hanya memiliki minat yang tinggi namun kemampuan kurang, maka karyawan tersebut harus ditingkatkan kemampuannya melalui kursus dan pelatihan kerja, namun jika karyawan memiliki kemampuan cukup tetapi tidak mempunyai motivasi yang tinggi, dapat diselesaikan dengan memberikan incentive untuk meningkatkan semangat kerja yang menurun.ada dua faktor yang mendorong karyawan termotivasi yaitu faktor intrinsik yaitu daya dorong yang timbul dari dalam diri masing-masing orang, dan faktor ekstrinsik yaitu daya dorong yang datang dari luar diri seseorang, terutama dari organisasi tempatnya bekerja. Jadi karyawan yang terdorong secara intrinsik akan menyenangi pekerjaan yang memungkinnya menggunakan kreaktivitas dan inovasinya, bekerja dengan tingkat otonomi yang tinggi dan tidak perlu diawasi dengan ketat. Kepuasan disini tidak terutama dikaitkan dengan perolehan hal-hal yang bersifat materi. Sebaliknya, mereka yang lebih terdorong oleh faktor-faktor ekstrinsik cenderung melihat kepada apa yang diberikan oleh organisasi kepada mereka dan kinerjanya diarahkan kepada perolehan hal-hal yang di inginkannya dari organisasi (Siagian, $2004: 107$ ).

(a) Motivasi intrinsik adalah motivasi yang tidak perlu dirangsang dari luar, karena dalam diri setiap individu sudah ada dorongan untuk melakukan sesuatu. Sebagai contoh seseorang yang senang membaca, tidak perlu ada yang menyuruh atau mendorongnya, ia sudah rajin mencari buku-buku untuk dibacanya. Maka yang dimaksud dengan motivasi intrinsik ini adalah ingin mencapai tujuan yang terkandung di dalam perbuatan belajar itu sendiri. (b)Motivasi ekstrinsik adalah motivasi yang menggunakan perangsang dari luar. Sebagai contoh seseorang belajar, karena tahu besok paginya akan ujian dengan harapan akan mendapatkan nilai baik, sehingga akan dipuji oleh pacarnya,atau temannya. Jadi yang penting bukan karena belajar ingin mengetahui sesuatu, tetapi ingin mendapatkan pujian. Jadi kalau dilihat dari segi tujuan kegiatan yang dilakukannya, tidak secara langsung bergayut dengan esensi apa yang dilakukannya. Oleh karena itu motivasi ekstrinsik dapat juga dikatakan sebagai bentuk motivasi yang aktivitas belajar dimulai dan diteruskan berdasarkan dorongan dari luar yang tidak secara mutlak berkaitan dengan aktivitas belajar.

Hasibuan (2009 : 150) menyatakan beberapa jenis motivasi, antara lain : (1) Motivasi Positif (Insentif positive) Manajer memotivasi karyawan dengan memberikan hadiah kepada mereka yang berprestasi baik. Dengan motivasi positif, semangat kerja karyawan akan meningkat karena umumnya manusia senang menerima yang baik-baik saja. (2) Motivasi Negatif (Insentif negative) Manajer memotivasi karyawan dengan memberikan hukuman kepada mereka yang pekerjaannya kurang baik 
(prestasi rendah). Dengan motivasi negatif semangat kerja karyawan dalam jangka waktu pendek akan meningkat karena mereka takut dihukum, tetapi untuk jangka waktu panjang dapat berakibat kurang baik. Berdasarkan dua jenis motivasi diatas, Hasibuan (2009 : 150) menyatakan bahwa motivasi diatas sering digunakan oleh suatu perusahaan. Penggunaannya harus tepat dan seimbang supaya dapat meningkatkan semangat kerja karyawan.

\section{Kesehatan dan Keselamatan Kerja}

Kesehatan dan Keselamatan Kerja (K3) merupakan upaya untuk menciptakan suasana bekerja yang aman, nyaman dan mencapai tujuan yaitu produktivitas setinggi-tingginya. Kesehatan dan Keselamatan Kerja sangat penting untuk dilaksanakan pada semua bidang pekerjaan tanpa terkecuali proyek pembangunan gedung seperti apartemen, hotel, mall dan lain-lain, karena penerapan K3 dapat mencegah dan mengurangi resiko terjadinya kecelakaan maupun penyakit akibat melakukan kerja.

Smith dan Sonesh (2011) mengemukakan bahwa pelatihan kesehatan dan keselamatan kerja (K3) mampu menurunkan resiko terjadinya kecelakaan kerja. Semakin besar pengetahuan karyawan akan K3 maka semakin kecil terjadinya resiko kecelakaan kerja, demikian sebaliknya semakin minimnya pengetahuan karyawan akan K3 maka semakin besar resiko terjadinya kecelakaan kerja.

Terjadinya kecelakaan kerja dimulai dari disfungsi manajemen dalam upaya penerapan Kesehatan dan Keselamatan Kerja (K3). Ketimpangan tersebut menjadi penyebab dasar terjadinya kecelakaan kerja. Dengan semakin meningkatnya kasus kecelakaan kerja dan kerugian akibat kecelakaan kerja, serta meningkatnya potensi bahaya dalam proses produksi, dibutuhkan pengelolaan K3 secara efektif, menyeluruh, dan terintegrasi dalam manajemen perusahaan. Manajemen K3 dalam organisasi yang efektif dapat membantu untuk meningkatkan semangat pekerja dan memungkinkan mereka memiliki keyakinan dalam pengelolaan organisasi.

Kecelakaan yang terjadi dalam hubungan kerja disebut kecelakaan berhubung dengan hubungan kerja yang artinya kecelakaan tersebut terjadi akibat pekerjaannya baik yang terjadi di tempat kerja maupun hendak pergi/pulang dari tempat kerja. Dalam hal ini kecelakaan kerja dapat terjadi akibat kondisi bahaya yang berkaitan dengan mesin, lingkungan kerja, proses produksi, sifat pekerjaan, dan cara kerja.

Kecelakaan kerja bisa juga terjadi akibat tindakan berbahaya yang dalam beberapa hal dapat dilatar belakangi oleh kurangnya pengetahuan dan keterampilan, cacat tubuh, keletihan dan kelelahan/kelesuan, sikap dan tingkah laku yang tidak aman ( Saloni Waruwu, Ferida Yuamita, 2016 ).

Menurut Widodo Siswowardojo (2003: 3), kesehatan kerja adalah peningkatan dan memelihara derajat kesehatan tenaga kerja setinggi-tingginya, baik fisik, mental maupun sosial, mencegah dan melindungi tenaga kerja terhadap gangguan kesehatan akibat lingkungan kerja dan faktor-faktor lain yang berbahaya, meningkatkan efisiensi kerja dan produktivitas, serta mengusahakan agar masyarakat lingkungan sekitar perusahaan terhindar dari bahaya pencemaran akibat proses produksi, bahan bangunan, dan sisa produksi.

Menurut Manullang (2000: 87), indikator kesehatan kerja yang meliputi:(a)Lingkungan kerja secara medis Dalam hal ini lingkungan kerja secara medis dapat dilihat dari sikap perusahaan dalam menangani hal-hal sebagai berikut : (1)Kebersihan lingkungan kerja(2)Suhu udara dan ventilasi ditempat kerja(3)Sistem pembuangan sampah dan limbah industri

(b) Sarana kesehatan tenaga kerja Upaya-upaya dari perusahaan untuk meningkatkan kesehatan dari tenaga kerjanya. Hal ini dapat dilihat dari penyediaan air bersih dan sarana kamar mandi (c) Pemeliharaan Kesehatan tenaga kerja yaitu pelayanan kesehatan tenaga kerja.

Menurut Widodo Siswowardojo (2003: 2), keselamatan kerja adalah keselamatan kerja secara definitif dikatakan merupakan daya dan upaya yang terencana untuk mencegah terjadinya musibah kecelakaan ataupun penyakit akibat kerja.

Menurut Moenir (2006:203), indikator keselamatan kerja adalah : (a)Lingkungan kerja secara fisik (1)Penempatan benda atau barang dilakukan dengan diberi tanda-tanda, batas-batas, dan peringatan yang cukup.(2)Penyediaan perlengkapan yang mampu untuk digunakan sebagai alat pencegahan, pertolongan dan perlindungan. (3) Perlengkapan pencegahan misalnya : alat pencegahan kebakaran, pintu darurat, kursi pelontar bagi penerbangan pesawat tempur pertolongan apabila terjadi kecelakaan seperti : alat P3K, tabung oksigen, perahu penolong di setiap perahu besar. (b)Lingkungan Sosial Psikologis Jaminan keselamatan kerja secara psikologis dapat dilihat pada aturan perusahaan mengenai berbagai jaminan pekerja yang meliputi : (1)Aturan mengenai ketertiban organisasi dan atau 
pekerjaan hendaknya diperlakukan secara merata kepada semua pegawai tanpa kecuali. Masalahmasalah seperti itulah yang sering menjadi sebab utama kegagalan pegawai termasuk para eksekutif dalam pekerjaan.(2) Perawatan dan pemeliharaan asuransi terhadap para pegawai yang melakukan pekerjaan berbahaya dan resiko, yang kemungkinan terjadi kecelakaan kerja yang sangat besar. Asuransi meliputi jenis dan tingkat penderitaan yang di alami pada kecelakaan. Adanya asuransi jelas menimbulkan ketenangan pegawai dalam bekerja dan menimbulkan ketenangan akan dapat ditingkatkan karenanya.(3) Penempatan benda atau barang dilakukan dengan diberi tanda-tanda, batasbatas, dan peringatan yang cukup.. (3)Lingkungan kerja secara medis Dalam hal ini lingkungan kerja secara medis dapat dilihat dari sikap perusahaan dalam menangani hal-hal sebagai berikut : (a)Kebersihan lingkungan kerja(b)Suhu udara dan ventilasi ditempat kerja(c)Sistem pembuangan sampah dan limbah industry (4)Sarana kesehatan tenaga kerja Upaya-upaya dari perusahaan untuk meningkatkan kesehatan dari tenaga kerjanya. Hal ini dapat dilihat dari penyediaan air bersih dan sarana kamar mandi

Pemeliharaan Kesehatan tenaga kerja yaitu pelayanan kesehatan tenaga kerja.Menurut Tunggal S.W (1996) tahapan keselamatan dan kesehatan kerja memiliki beberapa tahapan antara lain :(1)Perencanaan Identifikasi Bahaya, Penilaian, dan Pengendalian Resiko. Identifikasi bahaya, penilaian dan pengendalian resiko dari kegiatan produk barang dan tanda jasa harus dipertimbangkan pada saat merumuskan rencana untuk memenuhi kebijakan keselamatan dan kesehatan kerja, karenanya harus dipelihara dan ditetapkan prosedurnya.(2)Peraturan Perundangan dan Peraturan Lainnya. Organisasi harus menetapkan dan memelihara prosedur untuk inventarisasi dan pemahamaan keselamatan dan kesehatan kerja sesuai dengan kegiatan organisasi yang bersangkutan, manajemen organisasi juga harus menjelaskan peraturan perundang-undangan dan persyaratan lainnya kepada setiap tenaga kerja.(3)Tujuan dan Sasaran ManajemenTujuan dan sasaran kebijakan keselamatan dan kesehatan ditetapkan oleh sekurang-kurangnya harus memenuhi kualifikasi sebagai berikut:(1)Dapat diukur,(2)Satuan/indikator pengukuran,(3)Sasaran pencapaian,(4)Jangka waktu pencapaian (5)Indikator Kerja

Dalam menetapkan tujuan dan sasaran kebijakan keselamatan dan kesehatan kerja, organisasi harus menggunakan indikator yang dapat diukur sebagai penilaian kinerja keselamatan dan kesehatan kerja yang sekaligus merupakan informasi mengenai keberhasilan pencapain system manajemen K3

Suma'mur (1985: 27) mengemukakan bahwa tujuan keselamatan kerja pada tingkat perusahaan adalah:(1)Mencegah terjadinya kecelakaan. (2) Pencegahan terjadinya penyakit akibat kerja. (3)Pencegahan atau penekanan menjadi sekecil-kecilnya cacat akibat kerja. (4) Pengamanan material, pesawat-pesawat, instalasiinstalasi, dan lain-lain. (5) peningkatan produktivitas atas dasar tingkat keamanan kerja yang tinggi.(6)Penghindaran pemborosan tenaga kerja, modal, alat-alat, dan sumber produksi lainnya sewaktu bekerja.(7)Pemeliharaan tempat kerja yang bersih, sehat, nyaman, dan aman.

\section{Kerangka Pemikiran}

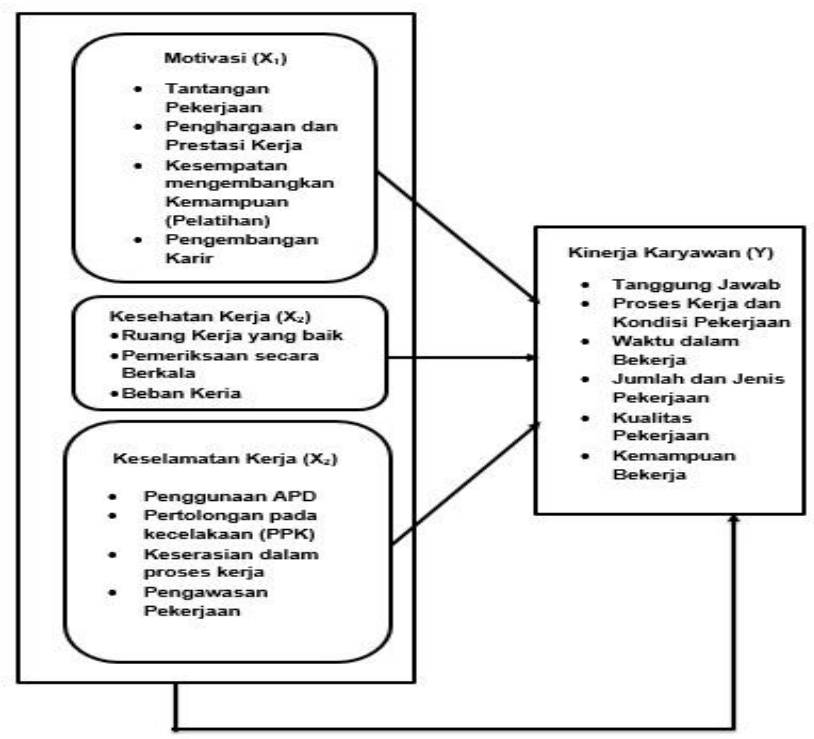

Gambar1. Kerangka Pemikiran 
(1) Kinerja atau Performance merupakan gambaran mengenai tingkat pencapaian pelaksanaan suatu program kegiatan atau kebijakan dalam mewujudkan sasaran tujuan visi dan misi organisasi yang dituangkan melalui perencanaan strategis suatu organisasi.Motivasi merupakan dorongan yang membuat karyawan melakukan sesuatu dengan cara dan untuk mencapai tujuan tertentu. (2) Kesehatan Kerja merupakan upaya untuk memelihara dan meningkatkan derajat kesehatan tenaga kerja pada suatu perusahaan yang memberikan jaminan untuk melindungi tenaga kerja terhadap gangguan kesehatan akibat kerja. (3) Keselamatan Kerja merupakan upaya untuk mencegah terjadinya insiden yang mungkin terjadi di lingkungan kerja dan untuk mengurangi resiko kecelakaan akibat kerja.

\section{METODE PENELITIAN}

\section{Jenis Penelitian}

Penelitian ini menggunakan metode kuantitatif dengan model Regresi linear parsial dan berganda dengan melihat seberapa besar pengaruh variabel bebas Motivasi $\left(\mathrm{X}^{1}\right)$, Kesehatan Kerja $\left(\mathrm{X}^{2}\right)$, dan Keselamatan Kerja $\left(\mathrm{X}^{3}\right)$ dengan variabel terikat Kinerja Karyawan (Y) dengan penyebaran kuesioner.

\section{Tempat dan Waktu Penelitian}

Penelitian ini dilakukan di PT. X didaerah Bumi Serpong Damai, mulai dari Oktober 2017 sampai Februari 2018.

\section{Populasi dan Sampel}

Populasi dalam penelitian iniadalah karyawan PT. X sebesar 70 orang dan sampelnya adalah 59 orang responden yang diambil berdasarkan tabel Morgan \& Krecjie.

\section{Definisi Oprasional}

Kinerja atau prestasi kerja adalah "sebagai hasil kerja yang telah dicapai seseorang dari tingkah laku kerjanya dalam melaksanakan aktivitas kerja. Motivasi adalah "faktor yang mendorong seseorang untuk melakukan suatu aktivitas tertentu, motivasi sering kali diartikan pula sebagai faktor pendorong perilaku seseorang".Kesehatan kerja adalah peningkatan dan memelihara derajat kesehatan tenaga kerja setinggi-tingginya, baik fisik, mental maupun sosial. Keselamatan kerja adalah keselamatan kerja secara definitif dikatakan merupakan daya dan upaya yang terencana untuk mencegah terjadinya musibah kecelakaan ataupun penyakit akibat kerja.

\section{Pengujian Validitas}

Apabila kuesioner telah memiliki validasi berarti semua pertanyaan yang ada di dalam kuesioner itu mengukur konsep yang akan di ukur. Maka dari itu harus dibuktikan dengan menggunakan rumus penghitungan uji korelasi Pearson correlation yaitu;

$$
r=\frac{N\left(\sum X Y\right)-\left(\sum X \sum Y\right)}{\sqrt{\left[N \sum X^{2}-\left(\sum X\right)^{2}\right]\left[N \sum Y^{2}-\left(\sum Y\right)^{2}\right]}}
$$

$$
\begin{aligned}
& \text { Keterangan: } \\
& \mathrm{N}=\text { Jumlah data } \\
& \mathrm{X}=\text { Skor item }
\end{aligned}
$$

Dari hasil penghitungan uji korelasi dapat disimpulkan dari nilai korelasi tersebut dinilai signifikan atau tidak nya dapat dilihat dari tabel signifikan nilai r product moment. Jika angka korelasi pada item (pertanyaan) tersebut berada diatas angka kritis signifikan, maka item tersebut bisa signifikan atau valid dan jika angka korelasi pada item tersebut berada dibawah angka kritis signifikan maka item tersebut bisa tidak valid dan harus di drop out.

\section{Pengujian Reabilitas}

Pengukuran reablitisan dengan menggunakan rumus Alpha Cronbach, sebagai berikut : 
Keterangan :

$\alpha=$ koefisien reliabilitas alpha

$\mathrm{k}=$ jumlah item

$\mathrm{Sj}=$ varians responden untuk item $\mathrm{I}$

$\mathrm{Sx}=$ jumlah varians skor total

Indikator pengukuran reliabilitas menurut Sekaran (2000: 312) yang membagi

tingkatan reliabilitas dengan kriteria sebagai berikut :

Jika alpha atau $r$ hitung:

$0.80<\mathrm{r}_{11} 1.00$ reliabilitas sangat tinggi

$0.60<\mathrm{r}_{11} 0.80$ reliabilitas tinggi

$0.40<\mathrm{r}_{11} 0.60$ reliabilitas sedang

$0.20<\mathrm{r}_{11} 0.40$ reliabilitas rendah

$-1.00<\mathrm{r}_{11} 0.20$ reliabilitas sangat rendah

\section{Uji Persyaratan Analisis}

\section{Uji Normalitas}

Uji normalitas berhubungan dengan kecukupan proporsi jumlah sampel. Hampir semua data penelitian dengan pengambilan sampel yang cukup memadai akan mempunyai distribusi normal dan homogen (suparman, $1995: 107$ ).

Untuk melakukan uji normalitas distribusi data, daoat digunakan uji Klomogorof-smirnov dari program SPSS. Normalitas distribusi data dihitung dengan cara membandingkan nilai AsymtoticSignificance yang diperoleh dengan nilai $\alpha=0,05$. Apabila Asymp.Sig $>0,05$, maka dapat dinyatakan normal (santoso,2004)

\section{Uji Heterokedasitas}

Uji ini bertujuan menguji apakah dalam model regresi terjadi ketidaksamaan varian dari residual satu pengamatan ke pengamatan yang lain. Model regresi yang baik adalah yang tidak terjadi heterokedastistas. Uji ini dengan menggunakan grafik Scatterplot.

\section{Uji Linearitas}

Uji linearitas ini digunakan untuk mengetahui apakah regresi yang diperoleh "berarti" apabila dipergunakan untuk membuat kesimpulan antar variabel yang sedang dianalisis. Pengujian linearitas variabel bebas dengan variabel terikat dilakukan dengan menggunakan One-Way Anova pada program SPSS dengan tarif signifikansi 5\% $(\alpha=0,05)$. Interpretasi linearitas data dilakukan dengan ketentuan jika $F_{\text {hitung }}<F_{\text {tabel }}$ maka variabel bebas dengan varibel terikat tersebut mempunyai hubungan yang linear.

\section{Regresi Linear Berganda}

Regresi linear berganda adalah sesuatu alat analisis peramalan nilai pengaruh dua variabel atau lebijh terhadap variabel terikat untuk membuktikan ada atau tidaknya hubungan fungsi atau hubungan kausal antara dua variabel bebas atau lebih $\left(\mathrm{X} 1, \mathrm{X} 2, \ldots . \mathrm{X}_{\mathrm{n}}\right)$. persamaan regresi berganda dirumuskan sebagai berikut :

$$
\mathbf{Y}=\mathbf{a}+\mathbf{b}_{1} \mathbf{X}_{1+} \mathbf{a}+\mathbf{b}_{2} \mathbf{X}_{2+} \mathbf{a}+\mathbf{b}_{3} \mathbf{X}_{3+} e
$$

Dimana:

$\mathrm{Y} \quad=$ Kinerja Karyawan

A $\quad=$ Konstanta

$\mathrm{b}_{1}, \mathrm{~b}_{2}, \mathrm{~b}_{3}=$ koefisien regresi variabel bebas

$\mathrm{X}_{1} \quad=$ Motivasi

$\mathrm{X}_{2} \quad=$ Kesehatan Kerja

$\mathrm{X}_{3} \quad=$ Keselamatan Kerja

$\mathrm{e} \quad=$ tingkat kesalahan

Model regresi berganda menggunakan program SPSS untuk menguji atau melihat pengaruh variabel motivasi, kesehatan kerja, keselamatan kerja terhadap kinerja karyawan. 


\section{Koefisien Deterimanis $\mathbf{R}^{2}$}

Untuk mengetahui seberapa jauh variabel bebas dapat menjelaskan variabel terkait, maka perlu diketahui koefisien determinasi atau penentuan nila $\mathrm{R}^{2}$ ini berkisar antara $0-1$, semakin mendekati 1 nilai $\mathrm{r}^{2}$ tersebut berarti semakin besar variabel independen (x) mampu menjelaskna variabel dependen $(\mathrm{Y})$. analisa terhadap nilai $\mathrm{R}_{\text {square }}$ atau $\left(\mathrm{R}^{2}\right)$ ini digunakan untuk mengetahui sejauh mana kedua variabel bebas $\left(\mathrm{X}^{1}\right.$ dan $\left.\mathrm{X}^{2}\right)$ Dapat menerangkan hubungan perubahan variabel terkait $(\mathrm{Y})$. Sifat-sifat $R_{\text {square }}$ sangat dipengaruhi oleh banyakanya variabel bebas, dimana semakin banyak variabel bebas

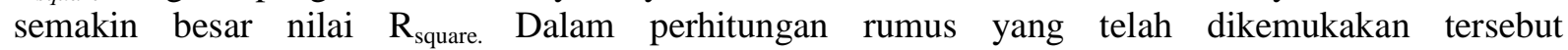
dilakukandengan proses SPSS.

\section{Uji Hipotesis}

Menurut Kelana Kusuma Negara (2011). Uji statistik digunakan untuk menguji hipotesis yang diajukan oleh peneliti. Hipotesis terdiri dari hipotesis null (Ho) dan hipotesis alternatif (Ha)(1)Hipotesis null (Ho) dinyatakan dalam kalimat yang menyatakan tidak ada hubungan antara variabel independen dengan variabel dependent atau tidak ada perbedaan antara beberapa pengukuran.Misalnya tidak ada hubungan antara variabel A dan variabel B.(2)Hipotesis kerja/hipotesis alternatif adalah pernyataan yang sesuai dengan jawaban sementara hasil penelitian yang diajukan oleh peneliti. Dinyatakan dalam kalimat sebaliknya, misalnya; terdapat hubungan antara variabel A dan variabel B.Semua jenis uji statistik menampilkan nilai propabilitas ( $\mathrm{p}$ value).

\section{Uji Secara Parsial}

(1) Hipotesis PertamaH $\mathrm{H}_{0}: \beta_{1}=0$, tidak terdapat Pengaruh Motivasi Terhadap Kinerja Karyawan PT X di Bumi Serpong DamaiH ${ }_{1}: \beta_{1} \neq 0$, terdapat Pengaruh Motivasi Terhadap Kinerja Karyawan PT $X$ di Bumi Serpong Damai(2) Hipotesis keduaH $\mathrm{H}_{0}: \beta_{2}=0$, tidak terdapat Pengaruh Kesehatan kerja Terhadap Kinerja Karyawan PT X di Bumi Serpong Damai. $\mathrm{H}_{1}: \beta_{2} \neq 0$, terdapat Pengaruh Kesehatan kerja Terhadap Kinerja Karyawan PT X Di Bumi Serpong Damai. (3) Hipotesis ketigaH ${ }_{0}: \beta_{3}=0$, tidak terdapat Pengaruh Keselamatan kerja Terhadap Kinerja Karyawan PT X di Bumi Serpong Damai. $\mathrm{H}_{1}: \beta_{3} \neq 0$, terdapat Pengaruh Keselamatan kerja Terhadap Kinerja Karyawan PT X Di Bumi Serpong Damai.Kriteria Pengujian : (a)Terima $\mathrm{H}_{0}$ Jika sig $\mathrm{t} \geq 0,05$ (b) Tolak $\mathrm{H}_{0}$ Jika sig $\mathrm{t}<0,05$

\section{Uji Secara Simultan (Uji F)}

Hipotesis Keempat $: \mathrm{H}_{1}: \beta_{1}=\beta_{2}=\beta_{3}=0$, tidak terdapat Pengaruh motivasi dan Kesehatan Keselamatan Kerja Terhadap Kinerja Karyawan PT X Di Bumi Serpong Damai. $H_{1}: \beta_{1} \neq \beta_{2} \neq \beta_{3} \neq 0$, terdapat Pengaruh motivasi Kesehatan Keselamatan Kerja Terhadap Kinerja Karyawan PT X di Bumi Serpong Damai. Kriteria Pengujian(a) $\mathrm{H}_{0}$ diterima Jika F.sig $\geq 0,05$. (b) $\mathrm{H}_{0}$ ditolak Jika F.sig $<0,05$

\section{ANALISIS DATA}

Tabel 1. Regresi Linear Sederhana

\begin{tabular}{llccccc}
\hline \multicolumn{1}{c}{ Model } & \multicolumn{7}{c}{ Coefficients $^{\mathbf{a}}$} \\
& \multicolumn{2}{c}{ Unstandardized Coefficients } & $\begin{array}{c}\text { Standardized } \\
\text { Coefficients } \\
\text { Beta }\end{array}$ & $\mathrm{T}$ & Sig. \\
\hline 1 & B & Std. Error & .271 & & 4.305 & .000 \\
& (Constant) & 1.167 & .411 & .789 & 3.647 & .001 \\
& Motivasi & 1.500 & .520 & .190 & .641 & .524 \\
Kesehatan Kerja & .333 & .381 & -.601 & -2.624 & .011
\end{tabular}

a. Dependent Variable: Kinerja Karyawan

(1) variabel Motivasi didapat hasil $t_{\text {hitung }}$ sebesar 3,647 dengan nilai signifikansi sebesar 0,001 dan didapat nilai standardize Coefficients Beta sebesar 0,789 yang dapat diartikan bahwa variabel bebas motivasi ada pengaruh yang positif dan signifikan terhadap variabel terikat Kinerja karyawan 
sebesar 78,9\%. maka H0 ditolak dan H1 diterima.(2)Variabel Kesehatan Kerja didapat hasil $\mathrm{t}_{\text {hitung }}$ sebesar 0,641 dengan nilai signifikansi sebesar 0,524 dan didapat nilai standardize Coefficients Beta sebesar 0,190 yang dapat diartikan bahwa variabel bebas Kesehatan kerja tidak ada pengaruh yang positif dan signifikan terhadap variabel terikat Kinerja karyawan sebesar 19\%. Karena nilai signifikan lebih dari 0,05 maka $\mathrm{H} 0$ diterima dan $\mathrm{H} 1$ ditolak. (3) variabel Keselamatan Kerja didapat hasil $\mathrm{t}_{\text {hitung }}$ sebesar -2,624 dengan nilai signifikansi sebesar 0,011 dan didapat nilai standardize Coefficients Beta sebesar -0,601 yang dapat diartikan bahwa variabel bebas Keselamatan Kerja ada pengaruh yang terbalik dan signifikan terhadap variabel terikat Kinerja karyawan sebesar -60,1\%. Maka H0 ditolak dan $\mathrm{H} 1$ diterima, yang berarti terdapat pengaruh yang terbalik (signifikan) dari variabel Keselamatan Kerja $\left(\mathrm{X}_{2}\right)$ terhadap variabel Kinerja Karyawan.

Tabel 2. Regresi Linear Berganda

\begin{tabular}{ccccc}
\multicolumn{6}{c}{ Model Summary $^{\mathbf{b}}$} \\
\hline Model & $\mathrm{R}$ & R Square & Adjusted R Square & $\begin{array}{c}\text { Std. Error of the } \\
\text { Estimate }\end{array}$ \\
\hline 1 & $.595^{\mathrm{a}}$ & .354 & .319 & .637 \\
\hline
\end{tabular}

a. Predictors: (Constant), Motivasi, Keselamatan Kerja, Kesehatan Kerja

b. Dependent Variable: Kinerja Karyawan

Besarnya nilai korelasi atau hubungan yaitu sebesar $0,595^{\mathrm{a}}$ dan besarnya nilai presentasi variabel bebas terhadap variabel terikat yang disebut koefisien determinan yang merupakan hasil dari penguadratan R. Dari hasil tersebut diperoleh nilai koefisien determinan (R2) sebesar 0,354 yang artinya bahwa pengaruh variabel bebas terhadap variabel terikat adalah sebesar $35,4 \%$ sedangkan sisanya dipengaruhi oleh hal lainnya.

Tabel 3. Uji Secara Simultan (uji F)

\begin{tabular}{ccccccc}
\hline \multicolumn{7}{c}{ ANOVA $^{\mathbf{b}}$} \\
\hline 1 & Model & Sum of Squares & Df & Mean Square & F & Sig. \\
\hline & Regression & 12.243 & 3 & 4.081 & 10.050 & $.000^{\mathrm{a}}$ \\
& Residual & 22.333 & 55 & .406 & & \\
Total & 34.576 & 58 & & & \\
\hline
\end{tabular}

a. Predictors: (Constant), Keselamatan Kerja, Motivasi, Kesehatan Kerja

b. Dependent Variable: Kinerja Karyawan

Ada pengaruh yang nyata antara variabel $\mathrm{X}$ terhadap variabel $\mathrm{Y}$ dimana $\mathrm{F}_{\text {hitung }} 10,050$ dengan tingkat signifikan probaliti $0,000<0,05$ sehingga Hipotesis diterima artinya variabel motivasi, kesehatan kerja, dan keselamatan kerja secara bersama-sama mempengaruhi kinerja karyawan Pt. X di Bumi Serpong Damai.

\section{KESIMPULAN DAN SARAN}

\section{Kesimpulan}

Variabel bebas Motivasi mempunyai pengaruh positif dan signifikan sebesar 78,9 \% terhadap variabel terikat Kinerja Karyawan PT X Di Bumi Serpong damai. Variabel bebas Kesehatan kerja tidak mempunyai pengaruh positif dan signifikan sebesar $19 \%$ terhadap variabel terikat kinerja Karyawan PT X Di Bumi Serpong damai. Variabel bebas Keselamatan Kerja mempunyai pengaruh yang terbalik dan signifikan sebesar $60,1 \%$ terhadap variabel terikat kinerja Karyawan PT X Di Bumi Serpong damai. Variabel bebas Motivasi, Kesehatan kerja, dan Keselamatan kerja secara bersamasama diuji $\mathrm{F}$ membuktikan mempunyai pengaruh positif dan signifikan terhadap Kinerja Karyawan besarnya pengaruh dapat dilihat dari nilai koefisien determinasi $\left(\mathrm{R}_{2}\right)$ sebesar $35,4 \%$ 


\section{Saran}

(1) Saran TeoritisHasil penelitian ini seharusnya dijadikan sebagai bahan kepustakaan dan literatur nyata, sehingga mahasiswa akan lebih memahami apa itu dampak akibat kurangnya memperhatikan motivasi kerja dan kinerja karyawan.

Hasil Penelitian ini dapat dijadikan sumber nyata dalam penelitian selanjutnya berkaitan dengan kinerja karyawan uintuk dapat digali lebih lanjut sehingga dapat mengekspor data yang lebih dalam lagi. (2) Saran Praktis (a) Bagi Direksi PT. XManagemen Perusahaan harus fokus meningkatkan motivasi, kesehatan kerja, dan keselamatan kerja karyawannya dengan tujuan mengurangi absensi dan turn over karyawan pada tahun selanjutnya. (b) Bagi SDM PT. XSeharusnya perusahaan memberikan lebih banyak pelatihan kerja bagi karyawan agar semakin termotivasi dalam bekerja karena karyawan akan semakin menguasai penuh pekerjaann yang akan dikerjakannya. (c) Bagi Karyawan PT. XSebaiknya karyawan melakukan pekerjaan sesuai dengan kompetensi di bidangnya untuk menghasilkan kinerja yang optimal.

\section{DAFTAR PUSTAKA}

Achmad Suryadi, Hamim Rosyidi , 2013. Kinerja Karyawan ditinjau dari Analisis Faktor Budaya Perusahaan. Jurnal Penelitian Psikologi 2013, Vol. 04, No. 02, 166-180

Anwar Prabu Mangkunegara, 2001, Manajemen Sumber Daya Manusia Perusahaan, Remaja Rosdakarya, Bandung. PT. Remaja Rosdakarya.

Aurelia Potu, 2013. Kepemimpinan, Motivasi, dan Lingkungan Kerja Pengaruhnya terhadap Kinerja Karyawan pada Kanwil Ditjen Kekayaan Negara Suluttenggo dan Maluku Utara.Vol.1 No.4 Desember 2013, Hal. 1208-1218

Bernardin, H. John \& Joyce E. A. Russell, 1993, Human Resource Management. Singapore: McGraw Hill Inc

Casio, Wayne F. (1992). Managing Human Resources: Productivity, Quality of Work Life, Profit. Singapore: McGraw-Hill International Editors

Donnelly, James H., Gibson, James L., and Ivancevich, John, 1994, Fundamental of Management. Texas: Business Publication.

Gravel Sylvie, Jacques Rheaume \& Gabbrielle Legendre. 2011. Strategies to Develop and Occupational Health and Safety Measures in Small Businnes Employing immigrant workers in Metropolitan Montreal. Journal International of workplace Health Management Vol 4 No 2

Hamzah. (2012). Teori Motivasi \& Pengukurannya. Jakarta: PT Bumi Aksara.

Hasibuan, Malayu S.P., 2011. Manajemen Sumber Daya Manusia. Bumi Aksara, Jakarta.

Hiskia Jonest Runtunuwu, Joyce Lapian, Lucky Dotulong, 2015. Pengaruh Disiplin, Penempatan dan Lingkungan Kerja Terhadap Kinerja Pegawai Pada Badan Pelayanan Perizinan Terpadu Kota Manado.Vol.3 No.3 Sept. 2015, Hal.81-89

Husein Umar, 2008. Manajemen Riset Pemasaran dan Perilaku Konsumen, Jakarta: PT. Gramedia Pusaka.

Julius Simbolon, 2017. Pengaruh K3 dan Lingkungan Kerja terhadap Kinerja Karyawan PT. Dwi Lestari Nusantara.Vol. 5. No. 2 Mei 2017

Kuncoro, Mudrajad, 2009. Metode Riset untuk Bisnis dan Ekonomi Edisi 3, Erlangga, Jakarta.

Kuswandi, 2004. Cara Mengukur Kepuasan Kerja. Elex Media Komputindo, Jakarta. Mangkunegara, Anwar Prabu, 2012. Evaluasi Kinerja SDM, Refika Aditama, Bandung.

M. Manullang, 2000, Manajemen Personalia, Jakarta, Ghalia Indonesia

Mathis.L.Robert dan Jackson.H.John. 2001, Manajemen Sumber Daya Manusia, Jakarta : Buku kedua.

Moenir. 2006. Manajemen Pelayanan Umum di Indonesia, Jakarta :PT. Bumi Aksara

Riptono $^{1}$, Muhammad As 'ad ${ }^{2}$, Mochamad Reza Hafriansyah ${ }^{3}$ (Pengaruh Motivasi, Kesehatan Kerja dan ...) 
Muslikah Eny, Upaya Peningkatan Kinerja Karyawan melalu Motivasi Kerja Pada PT. Sampurna Kuningan Juwana-Kabupaten Pati, 2011

Nani Sufiani Suhanda1, Amri Jahi2, Basita G. Sugihen, dan Djoko Susanto, 2009. Kinerja Dan Motivasi Penyuluh Pertanian di Provinsi Jawa Barat. September 2009 Vol. 5 No. 2

Notoatmodjo, S. 2007. Promosi Kesehatan dan Ilmu Perilaku. Jakarta : Rineka Cipta

Patricia M. Sahangggamu, Silvya L. Mandey 2014 "Pengaruh Pelatihan Kerja, Motivasi kerja dan Displin kerja terhadap Kinerja Karyawan pada PT. Bank Perkreditan Rakyat Dana Raya. Vol.2 No.4 Desember 2014, Hal. 514-523

Prasetyo, D. T., Musadieq, M. A., \& Iqbal, M. (2015). Pengaruh Kemampuan Kerja dan Lingkungan Kerja Terhadap Kinerja Karyawan (Studi Pada Karyawan PT. Tembakau Djajasakti Sari Malang).Jurnal Administrasi Bisnis (JAB) Vol 3 No. 1.

Prawirosentono, Suryadi. 1999. Kebijakan Kinerja Karyawan. Yogyakarta: BPFE.

Runtunuwu, H. J., Lapian, J., \& Dotulang, L. (2015). Pengaruh Disiplin, Penempatan dan Lingkungan Kerja Terhadap Kinerja Pegawai pada Badan pelayanan Perizinan Terpadu Kota Manado.Jurnal EMBA Vol.3 No.3, Hal. 81-91.

Sahangggamu, P. M., \& Mandey, S. L. (2014). Pengaruh Pelatihan Kerja, Motivasi dan Disiplin Kerja Terhadap Kinerja Karyawan Pada PT. Bank Perkreditan Rakyat Dana Raya.Jurnal EMBA Vol.2 No.4, Hal514-523.

Saloni Waruwu, Ferida Yuamita. Analisis Faktor Kesehatan dan Keselamatan Kerja(k3) yang signifikan mempengaruhi Kecelakaan Kerja pada Proyek Pembangunun Apartemen Student Castle.

Siagian, S. (2008). Manajemen Sumber Daya Manusia. Jakarta: PT Bumi Aksara.

Siagian, Sondang P. 2004. Manajemen Sumber Daya Manusia. Jakarta: Bumi Aksara.

Siswowardojo Widodo, 2003. Norma Perlindungan Ketenaga Kerjaan, Keselamatan dan Kesehatan Kerja. Yogyakarta

Sondang P Siagian. 2003, Manajemen Sumber Daya Manusia edisi satu, cetakan kesepuluh. Jakarta : Bumi Aksara

Sony Haryanto, 2012. Pengaruh Sistem Manajemen K3 terhadap Kinerja Karyawan pada PT XX. JURNAL ILMU-ILMU TEKNIK - SISTEM, Vol. 9 No. 3

Stephen P. Robbins, 1996. Perilaku Organisasi, Konsep, Kontroversi dan Aplikasi. Alih Bahasa : Hadyana Pujaatmaka. Edisi Keenam. Penerbit PT.Bhuana Ilmu Populer, Jakarta

Stolovitch, Harold D., and Keeps, Erica J., 1992, Handbook of Human Performance Technology A Comprehensive Guide for Analysis and Solving Performance Problem in Organizations. San Francisco: Jersey-Bass Publisher

Suardi, Rudi (2007). Sistem Manajemen Keselamatan dan Kesehatan Kerja. Jakarta: PPM.

Sugiyono. (2011). Metode Penelitian Kombinasi (Mixed Methods). Bandung: Alfabeta.

Sulistiyani, Ambar T. dan Rosidah. 2003. Manajemen Sumber Daya Manusia. Yogyakarta : Graha Ilmu.

Sumaecmur, P. 2004. Higiene Perusahaan dan Kesehatan Kerja. Jakarta: PT. Toko Gunung Agung

Sutrisno, Edy. 2013. Manajemen Sumber Daya Manusia, Edisi Pertama, Jakarta : Kencana

Syahrifadilla, Novi, 2012. "Pengaruh Lingkungan Kerja dan Pengembangan Karyawan terhadap Kinerja Karyawan PT. Carsurindo Superintendent Medan”, Jurnal Repository USU.

Uno, Hamzah., (2011), Teori Motivasi dan Pengukurannya: Analisis di Bidang Pendidikan, Bumi Aksara, Jakarta. 